\title{
Lloyd George and the Dual Monarchy, 1917-1918
}

\section{Gergely EGEDY}

\author{
Nemzeti Közszolgálati Egytelem, Közigazgatás-Tudományi Kar \\ National University of Public Service, Faculty of Public Administration \\ Ménesi út 5, 1118 Budapest, Hungary \\ gergely.egedy@gmail.com
}

This study makes an attempt to outline the role of Lloyd George in shaping the relations between Great Britain and Austria-Hungary in 1917-1918, i.e. in the second half of the First World War. Implicit in this statement is that the object of the study is much more modest than to attempt to analyze all aspects of British foreign policy toward the Habsburg Monarchy in this period. Lloyd George, the prime minister of Great Britain between December 1916 and October 1922, was only one of the decision-makers, who often could not realize his objectives. However, his aims and actions concerning the future of the Monarchy are worth studying even if they came to be frustrated by the spring of 1918 .

The study is primarily based on the "War Memoirs" of the ex-premier, written and first published in 1933-1936. The present author relied on the revised edition of 1936-1938, comprising some additional comments. ${ }^{1}$ As will be seen in what follows, Lloyd George attributed special significance to the conclusion of a separate peace with the Dual Monarchy; this is the reason of why he devoted most of his attention also in his memoirs (in respect of Austria-Hungary) to describe the secret talks aimed at detaching Vienna from Berlin.

\section{Great-Britain and Austria}

The stance of Lloyd George may be qualified to a significant extent as the continuation of a long political tradition. Britain looked upon Austria for centuries as an essential element in the European balance of power and thus the relations between the two great powers were usually cordial. Although the emerging crisis in the Balkans in the last third of the 19th century had tested the friendship of London and Vienna, the British ambassador to Vienna described the Monarchy as late as 1893 as a natural ally of Britain. ${ }^{2}$ Even the annexation of Bosnia in 1908, though heavily criticized by the Foreign Office, did not destroy the friendly British attitude to Austria-Hungary. ${ }^{3}$ The strength of this political tradition was clearly demonstrated by the remark of the Austrian Foreign Minister, Leopold von Berchtold to the last British ambassador when the diplomatic relation was broken off in August 1914: "It seems absurd for good friends like England and Austria to be at war". ${ }^{4}$

1 David LLOYD GEORGE, War Memoirs, I-II, London 1936-1938.

2 Alan J. P. TAYLOR, The Struggle for Mastery in Europe, 1848-1919, Oxford 1954, 342.

3 For an overview of the British-Austrian relations prior to World War I see: Alfred PRIBRAM, Austria-Hungary and Great Britain, 1908-1914, Oxford 1951.

4 Quoted by Wilfried FEST, Peace or Partition. The Habsburg Monarchy and British Policy, 1914-1918, London 1978,11 
After the outbreak of the war basically two conceptions crystallized in British political thinking in connection with the preferred future of the Austro-Hungarian Monarchy. One of them was the position taken by Robert W. Seton-Watson, a noted professor at Oxford and by Henry Wickham Steed, the correspondent of "The Times" in Vienna. They considered the Habsburg Monarchy to be a prison of the Slavic people and, consequently, they urged its complete dissolution. This orientation was reflected in the memorandum prepared by William Tyrrell and Robert Paget in August 1916: both of them held the view that the Dual Empire was a "negation" of the national principle and thus it had to be broken up by all means. ${ }^{5}$ Seton-Watson and Steed played a crucial part in setting up the journal "New Europe" which conducted an intense campaign for the dissolution of the Dual Monarchy. The majority of the experts in the Foreign Office embraced this approach towards Central Europe. As a consequence, the Foreign Office was bent on the dissolution of the Danube Monarchy.

However, there was a different orientation as well, which regarded the existence of the Habsburg Monarchy indispensable for the stability of Europe. The influential aristocrat, Lord Alfred Milner and some of Lloyd George's close associates and friends, including Leopold S. Amery, Jan Smuts and Philip Kerr sympathized with the idea of preserving a reformed Habsburg Monarchy - a viable political structure in Central Europe. The Milnerites and their political allies also wanted to destroy German dominance but they deemed the dissolution of the Monarchy unsuitable for the aim of countering the ,Mitteleuropa'- plans of Berlin. In his memorandum of August 1916 Sir William Robertson, the Chief of the General Staff also expressed his wish to keep the Habsburg Monarchy in existence. ${ }^{6}$ This pro-Habsburg orientation received a new and marked impetus in London after the death of Francis Joseph in November 1916 when the pacifist and markedly anti-Prussian Karl came to the throne. Upon his accession he made it clear that he was not prepared to fight at all costs and in his famous proclamation "To My Peoples" he declared his intention to finish the war as soon as possible. This stance suggested that the young Emperor was ready to detach his empire form Germany. The noted historian, Fest rightly emphasizes that from early 1917 a fierce struggle began in British political circles between the opponents and the supporters of the Dual Monarchy in order to win the sympathy of the public opinion. ${ }^{7}$ As for Lloyd George, he had not yet committed himself by the time he became prime minister in December 1916. In fact, he knew very little about Central Europe. Calder quotes him as saying in the summer of 1916 that he agreed with dismantling the Danube Monarchy. However, in the view of the present writer this particular case should not be overestimated because at that time he had not yet formed his opinion concerning the fate of the Dual Monarchy. In the same conversation referred to above Lloyd George asked H. A. I. Fisher, displaying an amazing lack of knowledge: „Who are the Slovaks? ... Where are they?"8 But he was a thoroughly pragmatic statesman who did not let various preconceptions guide his actions. The new peace-policy espoused by Karl led Lloyd George to suppose that

5 For this document see (in Hungarian translation): Lajos ARDAY, Térkép, csata után. Magyarország a brit külpolitikában, 1918-1919, Budapest 2009, 28-29.

6 The memorandum is printed in: LLOYD GEORGE, War Memoirs I, 499.

7 FEST, 88.

8 Kenneth J. CALDER, Britain and the Origins of the New Europe, Cambridge 1976, 101. 
the Dual Monarchy was on the way to detach itself from Germany. He convinced himself - taking into account the visible signs of the decline of Russian power as well - that a reformed Monarchy under Habsburg rule, transformed into a federation of its constituent nations could be a useful and effective counterweight to German ambitions in the eastern half of Europe. He was sure that such a solution would be fully consistent with the British interests. ${ }^{9}$ One should not forget that in respect of the Austro-Hungarian Monarchy the overriding priority in British foreign policy was whether this strange political configuration could be evaluated as a potential German ally or - in the long-run - as a potential rival and opponent of Germany. Lloyd George was inclined to accept the latter approach.

\section{The first round of the secret negotiations: Sixtus, Ribot and Lloyd George}

It can be established with certainty that in Lloyd George's reading the issue of the future of the Dual Monarchy had a close connection with the chances of detaching Vienna from Berlin and the conclusion of a separate peace. This explains why his memoirs concentrate on the secret negotiations. The key figure in the first round of these talks was Prince Sixtus. His activity has already been analyzed in some works; this study aims to reconstruct the events from the point of view of Lloyd George. ${ }^{10}$ For this purpose - besides the "War Memoirs" - another important source has been utilized too, namely the description of the talks by Prince Sixtus himself. His recollection was translated into English and published in 1921, edited by Georges de Manteyer under the title "Austria's Peace Offer, 1916-1917". This work includes his discussions with Lloyd George as well. ${ }^{11}$

In his memoirs Lloyd George describes the Austro-Hungarian Monarchy as "ramshackle" but does not offer a deeper analysis of its internal condition. He stresses however, that the "liberal and pacifist" Karl came to the conclusion that his empire was heading for a catastrophe, if it followed Germany blindly. He saw clearly that "if the Central Powers were ultimately victorious, Austria might expect to become, for all practical purposes, a vassal of Germany". ${ }^{2}$ Lloyd George also pointed out that the wife of Karl, Empress Zita was a Bourbon who had no love for Prussia and no hatred of France. It is no wonder, he concludes, that "Karl and his intelligent consort looked out longingly for an early peace without victory or defeat". ${ }^{13}$ In his opinion it was this realization that moved the young Emperor to initiate secret talks with the Entente to find out the conditions of peace. This was all the more important for Karl because, as is well known, the Western allies called the "liberation of the Italians, also of the Slavs, Rumanians and Czecho-Slovaks from foreign domination", i.e. the dismantling of his empire was one of their major war-aims in their

9 The noted researcher of this issue, Harry Hanak also stresses: "Lloyd George...had little sympathy with the plan to destroy Austria-Hungary." Harry HANAK, Great-Britain and Austria-Hungary during the First World War. A Study in the Formation of Public Opinion, London 1962, 274.

10 For a general overview of the Sixtus mission see: Robert A. KANN, Die Sixtusaffäre und die geheimen Friedensverhandlungen Österreich-Ungarns im Ersten Weltkrieg, Wien 1966.

11 Georges de MANTEYER (ed.), Austria's Peace Offer, 1916-1917, London 1921.

12 LLOYD GEORGE, 1176.

13 lbidem, 1176. 
reply of January 10 to the peace proposal of the American president Woodrow Wilson. ${ }^{14}$ Vienna was deeply disappointed with the Allies' reply.

We get to know from the memoirs that Lloyd George first heard of the informal peace moves of Vienna from Sir M. Findley, the British ambassador in Oslo (Christiania) in January 1917. The British prime minister sent a special envoy to Oslo, Stockholm and Copenhagen but Sir Francis Hopwood did not succeed in meeting any Austrian diplomats. Lloyd George was sorry for this because he did not wish to neglect any opportunity to detach the Dual Monarchy "from the powerful combination we were fighting". ${ }^{15}$

He was even more disappointed to be informed that the last ambassador of Austria-Hungary to London, Count Albert Mensdorff had also arrived in the meantime to Scandinavia but Hopwood had failed to meet him. He reminds his readers that Mensdorff was a very popular figure in the British capital, well-known for his friendly feelings toward Britain. ${ }^{16}$ Hopwood was greeted by the King of Norway who told him that Mensdorff "was ,triste', very worried". ${ }^{17}$

Lloyd George assumes in his memoirs that Vienna's moves to seek contacts in Scandinavia were stopped because at the end of January Karl had decided to accept the help of his Bourbon brother-in-law, Zita's brother Prince Sixtus, offering to act as mediator between the Entente and the Monarchy. ${ }^{18}$ The "War Memoirs" give a detailed overview of the Sixtus mission - one of the last examples of dynastic diplomacy in European history - from the British viewpoint. ${ }^{19}$

On 13 February Karl empowered Prince Sixtus by way of his special envoy to inform Paris that Vienna was ready to support not only the restoration of the sovereignty of Belgium but also the French demand for the return of Alsace-Lorraine. ${ }^{20}$ This offer was certainly promising for Britain too, but Lloyd George did not fail to remark in his memoirs that the Emperor had not alluded at all to the key problem, to Italy which had enormous territorial claims on Austria. He added: "This attitude was maintained throughout the subsequent negotiations and was largely responsible for their failure." 21

Upon receiving Karl's message Prince Sixtus asked for some written documents that he could pass on to the French government as a basis for diplomatic talks. On 21 February

14 CALDER, 104.

15 LIOYD GEORGE, 1178.

16 lbidem, 1176. We can add that Mensdorff had family connections with the British court and this fact greatly increased British confidence in him. His deep sympathy with Britain even aroused some suspicion in certain cirles in Vienna.

17 LLOYD GEORGE, 1176.

18 Sixtus and his younger brother, Xavier were fighting against Germany in the army of Belgium after their request to be enlisted in the French army had been rejected on the basis of a law that prohibited members of the former royal families of France from seving in the army. In more details see: MANTEYER, 1-31.

19 From the French point of view one gets an excellent survey of the history of the Sixtus mission in the work of the emigrant Hungarian historian, Fejtő. See: Ferenc FEJTÖ, Requiem pour un empire défunt: Histoire de la destruction de l'Autrich-Hongrois, Paris 1988; the Czech edition: Rekviem za mrtvou říši: o zkáze RakouskaUherska, Praha 1998, the Hungarian edition: Rekviem egy hajdanvolt birodalomért - Ausztria-Magyarország szétrombolása, Budapest 1990, 172-210 (Chapters XVII-XIX).

20 LLOYD GEORGE, 1179; MANTEYER, 37.

21 LLOYD GEORGE, 1179. 
he got a note from Ottokar Czernin, the Foreign Minister of the Dual Monarchy who had been drawn into the secret action only after some delay. ${ }^{22}$ Lloyd George qualified this note as representing an attitude which was much more unfavorable to the Entente than the original verbal message of the Emperor. In his words: it was "of a very unaccommodating nature". Czernin declared emphatically that the alliance between Austria-Hungary and Germany was "absolutely indissoluble". ${ }^{23}$ It would be difficult to call into question the validity of Lloyd George's evaluation in the "War Memoirs": "The tone as well as the terms of Czernin's Memorandum would not have evoked on the Allied side any desire for further negotiations." 24 However, Karl attached a hand-written note the tone of which was much friendlier. In this he expressed again his support for the French claim on Alsace-Lorraine and posited that Austria-Hungary had no territorial ambitions. ${ }^{25}$ Though the term "separate peace" had not been used, the Emperor's approach differed markedly from that of his Foreign Minister. There is no doubt that both of them wished the war terminated as soon as possible, but their attitudes to the idea of a separate peace differed fundamentally. It took some time for Lloyd George to realize that Czernin was consequently and resolutely against the conclusion of a separate peace while Karl seriously considered it.

These two documents had been submitted to the French President Raymond Poincaré who asked for more information from Vienna. It was for this reason that the Prince (with his brother Xavier) called upon the Emperor at his castle at Laxenburg on 22-24 March. Karl told him that if he could not persuade the Germans to conclude peace, he would certainly not sacrifice his empire "to the insane obstinacy of his neighbors", i.e. for the sake of Prussian ambitions. ${ }^{26}$ The Emperor summarized his views in a long letter written on 24 March - Lloyd George thought it important to include it in his memoirs. (This is the famous "Sixtus-letter", addressed formally to the prince.) ${ }^{27}$ Though he basically felt sympathy for the attitude of Karl, he added sarcastically that while the latter "showed the greatest readiness to give up Germany's conquests from 1870 to 1917", he was not willing to surrender any territory to Italy. ${ }^{28}$

Not much later Lloyd George had the opportunity to read the letter of Karl: on 11 April the new French prime minister, Alexandre Ribot crossed over to Folkestone and showed it to his British counterpart - under a strict pledge of secrecy. Consequently, Lloyd George did not even inform his cabinet colleagues of the mission of Sixtus (only the King knew of it). He was of the view that the negotiations with Vienna should be started as soon as possible but he wanted also, to include the Italians. He thought it indispensable to sound

22 For the account of Zita concerning Czernin's inclusion see: Gordon BROOK-SHEPHERD, The Last Habsburg, London 1968, 68-69.

23 LLOYD GEORGE, 1179. For the stance of Czernin see his memoirs which were published right after the war: Ottokar CZERNIN, Im Welktriege, Wien 1919. Unfortunately Czernin says very little about the deatils of the secret talks but his work offers a general summary of his views on the war and thus helps us in understaning better the Viennese perception of Britain's moves.

24 LLOYD GEORGE, 1180.

25 LLOYD GEORGE, 1180; MANTEYER, 53.

26 MANTEYER, 74

27 LLOYD GEORGE, 1182-1184; MANTEYER, 83-84 (In a slightly different translation).

28 LLOYD GEORGE, 1182. However, he was convinced that the Italian claims - including Trentino, Trieste and a large part of Dalmatia - were extremely exaggerated. 
Baron Sidney Sonnino, the foreign minister of Italy. Though Ribot was much less inclined to search for a compromise with Austria-Hungary than his predecessor, Aristide Briand, the two premiers decided to hold a French-British-Italian summit where the issue of the Karl's peace initiatives could be debated.

However, it soon turned out that Prince Sixtus vehemently opposed the idea that the Italians should be informed of the letter of Karl. The reason is not difficult to find: he was afraid that the Italian government, not being interested in a separate peace with the Habsburg Monarchy without achieving all its objectives, would try to frustrate the peace efforts. It could even have deliberately disclosed the secret negotiations to Germany. It appears clearly from the "War Memoirs" that Lloyd George was fully aware of the fact that the public opinion in Austria was heavily against any concession to Italy, accused of betraying the Triple Alliance. ${ }^{29}$ Nevertheless, the memoirs demonstrate that their author was committed to starting the talks at once, since he held a separate peace with the Dual Monarchy crucial. ${ }^{30}$

On 18 April Lloyd George met Sixtus for the first time personally: he made an attempt to ask permission from him to disclose the secret mission to the Italians but the prince definitely turned down this request. The latter also gives his own account of the meeting that took place in Paris at the Hotel Crillon in the late evening hours. For this study it is of special relevance that the British prime minister is quoted as declaring: "We have an old feeling of friendship towards Austria. We would willingly shake hands with her even today if she would leave Germany..." ${ }^{31}$ Lloyd George also asked him whether Austria "was not playing the game of Germany", referring to the meeting of William and Karl at Homburg on 3 April. This suggestion was most resolutely refuted by the prince.

The French-British-Italian summit took place on the following day, on 19 April, in St. Jean de Maurienne. In keeping with the verbal agreement between Ribot and Lloyd George the question of a separate peace with the Dual Monarchy came to be discussed without mentioning the Emperor's letter. (Thus the urgency of the issue was presented as based upon "rumors" from "various sources" according to which Vienna was contemplating to break with Berlin.) In his memoirs Lloyd George stresses that he wanted to convince the Italians by all means of the significant strategic gains deriving from such an arrangement; he even offered territory to them in Turkey. He pointed out that if the Habsburg Monarchy made a separate peace with Russia, it would affect most dramatically Italy because large Austro-Hungarian forces would then become available for concentration against it. ${ }^{32}$ However, the Italian foreign minister, Sonnino rejected all of his arguments by saying that it would be very difficult to induce Italian public opinion the carry on the war if peace were made with the arch-enemy Austria without meeting all of the Italian demands.

29 LLOYD GEORGE, 1185.

30 In his recollection Count Czernin also acknowledges that Britain was inclined to reach an agreement with Vienna and conclude a separate peace. In defence of his own position, rejecting the British approach Czernin stresses that as a precondition of peace London insisted on the conditions deriving from the secret treaties. CZERNIN, 225-226. ("Was die Monarchie anbelangt, so schiene England bereit, mit derselben einen Separatfrieden, allerdings unter Einhaltung der den eigenen Bundesgenossen gegebenen Zusagen, zu schliessen. ") It means that he did not take into account the possibility that was alluded to by Lloyd George: in case of a successful separate peace London might have been willing to reconsider the promises made earlier.

31 MANTEYER, 114.

32 LLOYD GEORGE, 1187. 
After the unsuccessful summit Lloyd George met again Sixtus on 20 April in Paris and informed him of the obstinacy of the Italians. The prince responded by saying that in light of this Italian reaction Austria-Hungary would hardly be willing to consider the Italian claims at all. Lloyd George also looked upon Rome's claims as overly exaggerated, but he called the attention of Sixtus to the fact that with American help the Allies would be capable to continue the war for as long as they wished - and this fact should also be taken into account by Karl. It is worth remarking that Lloyd George did not suggest to Sixtus that Vienna should meet all the demands of Rome, he only suggested that she must sacrifice "something" to Italy. ${ }^{33}$

\section{The alleged Italian offer - and its diplomatic consequences}

At this point there seemed to be no use in continuing the secret negotiations, but the British prime minister did not wish to renounce his strategic plan of detaching Austria-Hungary form Germany. Therefore he did not agree with the policy of his French colleague who was ostensibly playing for time even after a new turn had taken place in respect of the chances of a separate peace. The emissary of Karl, Count Erdődy informed Prince Sixtus in Neuchatel on 4 May that Vienna had received a promising offer from Italy - allegedly with the consent of the King but without the knowledge of the "hard-liner" foreign minister. This offer asked for only that part of South Tyrol which was inhabited by Italians - and for nothing else. Historians have not been able to convincingly prove or refute whether such an approach had in fact taken place or not. ${ }^{34}$ Zeman supposes, it may have been „Emperor Karl's clumsy attempt to deceive".$^{35}$ However, one thing can be stated with certainty: Lloyd George was willing to give credit to the words of Karl, supposing, rightly, that the Italian army was in a demoralized condition (a fact which came to be corroborated by the devastating defeat at Caporetto in the autumn of 1917). ${ }^{36}$ Lloyd George found it especially important that Karl had displayed some willingness to cede Trentino for the sake of a separate peace with the Allies. However, Ribot was not interested in the alleged Italian proposal and wished to shelve the issue of the separate peace. ${ }^{37}$ The present author is inclined to agree with the view of Brook-Shepherd that from about this time "the Sixtus affair... is virtually taken over by the Prime Minister of Britain", with Ribot sliding deliberately out of the picture and Lloyd George coming more and more to the forefront. ${ }^{38}$

On 14 May Lloyd George wrote a letter to his French counterpart, stressing that the secret Italian move and the apparent flexibility of Vienna were such important developments that should not remain unheeded. He called the information forwarded by Erdődy "of

33 MANTEYER, 119 ("It is essential that Austria give up something to Italy").

34 FEST, 73.

35 Zbyněk A. B. ZEMAN, A Diplomatic History of the First World War, London, 1971, 135. On the contrary, Empress Zita told Brook-Shepherd that it had been an action of the commander of the Italian army, General Cadorna, and her husband did not want "to get into complications with Italy before a final answer arrived from the 'Entente'." See: BROOK-SHEPHERD, 84-85.

36 LLOYD GEORGE, 1189.

37 LLOYD GEORGE, 1195.

38 BROOK-SHEPHERD, 87. 
grave importance", and it is evident from his letter, quoted in full in his memoirs that he advocated a new summit about this issue. ${ }^{39}$ The reply of the French premier arrived on May 20: Ribot evaded the proposal and instead of a definite answer informed Lloyd George that Prince Sixtus would soon visit him in London with a very important "autograph" letter. As for the alleged Italian offer to Vienna he expressed his view that it could not have been endorsed by the king.

Sixtus did arrive in London on 22 May and the next day he visited Lloyd George at Downing Street. The document he brought with himself was the letter of Karl, written on 9 May to corroborate the information passed on verbally by Count Erdődy that Rome would be content with the Italian part of South Tyrol. ( with a demand for peace.... She has limited her claim to the Italian-speaking portion of the Tyrol" - wrote the Emperor.) The letter struck a markedly friendly chord with France and Britain. However, a much less constructive attitude was again displayed in the note of Count Czernin, attached to the Emperor's letter. Lloyd George was right in interpreting the words of the foreign minister as a virtual rejection of meeting any Italian demands. ${ }^{40}$ By that time he had come to see clearly that the priorities of Karl and Czernin were far from identical.

Sixtus also gives his own account of their meeting on 23 May. According to him Lloyd George asked if Vienna would be satisfied if - in exchange for the cession of Trentino - it would get Eritrea and Somaliland from Rome. The prince qualified such a solution as a complete nonsense from the Austrian point of view. ${ }^{41}$ It is also of interest to us that the British prime minister told him that "it was simply a waste of time to let so important a question be discussed by men who were not authorized to speak for their countries"; in other words he suggested that the top leaders - i.e. Czernin, Ribot and himself - should meet. $^{42}$

The "War Memoirs" go a long way to convince the readers that the French did not regret at all that the separate peace with the Dual Monarchy had failed to come about. In Lloyd George's opinion the main reason for this was their view that "the peace between Austria and Italy would benefit those two Powers only and not France". ${ }^{43}$ Paris assumed that after the conclusion of peace Italy would leave the war and would thereby enjoy a more favorable position than France. In fact, the French ambassador to London, Paul Cambon tried to convince Sixtus, that "he would really be doing France no service if he carried the negotiations through successfully." 44 Lloyd George, however, was absolutely sure that the possible defection of Italy "would be compensated tenfold” by separating the Habsburg Monarchy from Germany. In his reading the failure of the efforts aiming at a separate peace

39 LLOYD GEORGE, 1196.

40 LLOYD GEORGE, 1197-98. Czernin declared: "a one-sided cession of territory on the part of Austria-Hungary is out of the question; in the event of a compenastion by counter-cession the idea could be discussed, provided that account is taken of the fact that the ground heroically defended and watered with the blood of our soliders has for us incomparably higher value than any new territory".

41 MANTEYER, 168.

42 MANTEYER, 169.

43 LLOYD GEORGE, 1200.

44 LLOYD GEORGE, 1201; MANTEYER 173, 174. 
with Vienna could be attributed to the petty-minded jealousy of the French. In his memoirs we find the following succinct formulation: "Cleverly and with every appearance of helping them along, the Sixtus, pourparlers' were maneuvered into futility. (...) The British Government was helpless". ${ }^{45}$ It may be reasonably assumed that if France had resolutely supported Lloyd George, Sonnino could have been compelled to revise Italy's claims on Austria.

For some time Sixtus remained in England, on the island of Wight, waiting for some answer from Italy to Lloyd George's proposal to hold a meeting of the top leaders. By that time the prince he had lost his hope in cooperating successfully with France - and probably also in the success of his mission. According to Lloyd George Paul Cambon's abovementioned words also contributed to disheartening the prince; they "must have cooled his zeal" because it must have been quite difficult for him to face an insinuation that "he had bargained away the interests of France to serve an enemy relative". ${ }^{46}$ On 5 June Sixtus met once again Lloyd George who reassured him that his position concerning the separate peace had not changed at all; ( „The chance of peace with Austria is too important for us to let it slip." $)^{47}$ But the British Prime Minister could do nothing else than express his deepest regret - and the prince returned to his regiment... ${ }^{48}$

\section{The second round of the negotiations: Smuts and Mensdorff}

By the autumn of 1917 the international situation changed significantly. As for AustriaHungary, London received a growing number of reports about the worsening economic conditions and the increasing political tension within the multiethnic empire; these developments gave ground to suppose that the young Emperor was keener than ever to finish the war as soon as possible. On the other hand, however - and the "War Memoirs" do not fail to stress it - the ,Entente' also faced increasing difficulties after the crushing failure of its offensive in Flanders and the collapse of Russia.

This background explains that when it was intimated to London that Count Czernin wished to send Count Mensdorff to Switzerland to meet a representative of the British Cabinet in order to discuss the conditions of peace, Lloyd George did not hesitate to give a positive answer. In his eyes Mensdorff was "a highly acceptable emissary". ${ }^{49}$ We find the following

45 LLOYD GEORGE, 1201. Prince Sixtus had roughly the same impression about the attitude of the French government and in his memoirs he characterized Ribot with the following words: "Could see all the difficulties of the undetaking but could see nothing more". MANTEYER, 164.

46 LLOYD GEORGE, 1201.

47 LLOYD GEORGE, 1202.

48 Let us add that though the prime minister was not in a position to show Karl's letters to his colleagues, he urged them to support his endeavours to detach Austria-Hungary from Germany. His efforts included the espousal of the idea of radically changing the military strategy of the 'Entente'. Thus in June 1917 he suggested that the next large offensive of the Allies should not be conducted in Flanders as the Imperial General Staff planned but directly against Austria, concentrating on the Italian front, with a view to compel Vienna to make a separate peace. (As is known, the generals ignored the premier's pleas.) The memoranda compiled by Sir Maurice Hankey, Secretary to the Cabinet, tell much about Lloyd George's efforts in this respect. See in more details: BROOK-SHEPHERD, 92-96.

49 LLOYD GEORGE, 1478. 
remark in the "War Memoirs": "we felt that the dispatch of such a messenger constituted the best proof that the Austrian Government was in earnest in seeking a peaceable accommodation of the bloody quarrel". ${ }^{50}$ The prime minister looked for a person worthy of Mensdorff - and he chose his close associate, the former Boer military leader, General Smuts, a member of the War Cabinet who - by and large - shared his approach to British political priorities. In the words of Calder Smuts was „one of the most enthusiastic advocates of a separate peace". ${ }^{51}$ Lloyd George gave him strict instructions to confine himself to the discussion of a separate peace with the Habsburg Monarchy and not to be drawn into negotiations about the terms of a general peace. ${ }^{52}$

Lloyd George presents the talks between Smuts and Mensdorff by including the personal report of Smuts into his memoirs. Smuts was not only a highly gifted politician but also a meticulous person; therefore we do not risk much by relying on his notes in trying to reconstruct the secret negotiations, keeping in mind that he represented the position of Lloyd George.

Smuts arrived in Geneva on 18 December and on that day he met three times with the Austrian diplomat. In the morning he had a short interview with Count Mensdorff, in the afternoon they had a long conversation and a third conversation in the evening (at the request of Mensdorff on 19 December they had yet another meeting). ${ }^{53}$ In his own interpretation Smuts had two main objects: first of all to make it clear to Mensdorff that in case the Dual Monarchy freed itself from German domination and "made a fresh start in sympathy with the British Empire", it would have the full support of London. ${ }^{54}$ His second object was to gather as much information as possible concerning the plans of the Central Powers. His mission aimed, of course, to persuade the Dual Monarchy to conclude a separate peace but it soon turned out that Vienna was not willing to run this risk. Smuts writes that Mensdorff "saved him from the difficulties" by taking the initiative in declaring that this option was "out of the question". "Austria was prepared to do anything to secure an honourable peace short of deserting her ally during the War" - he stressed. ${ }^{55}$ We must add that Mensdorff only followed the instructions of his boss, Count Czernin.

However, Smuts stuck to his point and went on to explain the British position representing the view of Lloyd George. To begin with: he pointed out that "the friendly feeling towards Austria which had existed among the British people before the War had by no means disappeared, that a great deal of sympathy continued to be felt for Austria..." 56 His arguments were based on the supposition that the downfall of Russia resulting from the communist revolution had created a power vacuum in the eastern half of Europe. This vacuum would be filled with Germany unless some counterweight was established to the

50 LLOYD GEORGE, 1478.

51 CALDER, 122.

52 LLOYD GEORGE, 1478.

53 LLOYD GEORGE, 1487.

54 LLOYD GEORGE, 1478.

55 LLOYD GEORGE, 1479.

56 LLOYD GEORGE, 1479. Mensdorff remarked that he was gratified to hear this because the reply of the Allies to President Wilson's note in January 1917 had indicated the intention to break up the Habsburg Monarchy. See: LLOYD GEORGE, 1480. 
ambitions of Berlin. Could the Habsburg Monarchy not fulfill the role of this counterweight after a thorough internal restructuring? The question implied the answer. Smuts and Lloyd George were convinced that a reformed Habsburg Monarchy, after emancipating politically her Slavic nations would be able to counterbalance imperial Germany - and in this effort she would have not only the sympathy but also the "active support" of Britain. ${ }^{57}$ The report and the comments in the memoirs demonstrate that Smuts and Lloyd George had in mind not only the immediate needs of winning the war but they also took into account the ensuing situation after the war. There can be no doubt that the prime minister wanted the reformed Monarchy to play a key regional role. It is worth noting that the strategic position of the multiethnic state envisaged in the report by Smuts was in keeping also with the plan drawn up by Sir Eric Drummond on 10 December 1917. This memorandum also espoused - contrary to the preferences of the experts of the Foreign Office - the preservation of the reconstituted Monarchy which was to be a federation of five states, besides Austria and Hungary also Bohemia, Poland and Yugoslavia, including Serbia. ${ }^{58}$ Smuts pointed out to Mensdorff that such a new federation under the rule of the Habsburg dynasty "would have a mission in the future even greater than her mission in the past" ${ }^{59}$

Mensdorff assured him that the decision had already been taken to transform the Dual Monarchy fundamentally but the end of the war was a precondition of implementing the necessary changes. He even expressed his regret that "no word of sympathy had come from England for the policy stated by Czernin". ${ }^{60}$ In his view London should have taken steps to help the peace-efforts of Austria-Hungary. He also said that even within Germany significant changes were to be expected and he raised the issue of peace negotiations between London and Berlin. He suggested that Austria-Hungary could be used as an intermediary. ${ }^{61}$ The present author assumes that the major aim of Mensdorff's mission in December 1917 was to further a British-German ,rapprochement' but Smuts, acting on the instructions from Lloyd George, declined resolutely to discuss the terms of the general peace. He made it clear that he had been authorized to negotiate solely about Austria-Hungary. Czernin wanted to act as a mediator between the two military alliances but Britain was interested only in detaching Austria-Hungary from Germany. Zeman is right in stating that a separate peace was considered seriously by Vienna only in the case of the negotiations by Sixtus - and "then only by the Emperor, not by his Foreign Minister".62 Commenting upon the British attitude that rejected the discussion of the general terms of peace, Mensdorff declared to Smuts gloomily during their third, evening conversation: „in that case there was no peace in sight and this horrible War must go on". He added: Europe

57 LLOYD GEORGE, 1479-1480.

58 CALDER, 124.

59 LLOYD GEORGE, 1480. Smuts even compared the future role of the reconstituted Monarchy to that of the British Empire: "she would become for Central Europe very much what the British Empire had become for the rest of the world." Zeman rightly points out that as a man who had fought against the British and then became their ally Smuts might have thought that his views carried a special authority. See also: ZEMAN, 154.

60 LLOYD GEORGE, 1481.

61 LLOYD GEORGE, 1482.

62 ZEMAN, 1971, 160. 
"was dying at the centre", with America becoming the leading world power. ${ }^{63}$ Mensdorff proved to be prophetic in this respect.

The conversation also drifted to territorial questions. Smuts asked Mensdorff what concessions the Dual Monarchy was prepared to make in respect of those states (Serbia, Roumania, Italy) which had received in 1915-1916 various promises from the Allies. According to Mensdorff Serbia presented no special problem and he did not reject the suggestion of Smuts that Bosnia-Herzegovina should be added to Serbia (though he did not openly commit himself). However, he became "somewhat excited" when Smuts mentioned Roumania. The Austrian diplomat resolutely declared that "Roumania was finished and that they would do nothing for that treacherous State", adding that "Hungary would refuse to surrender an inch of territory to Roumania". ${ }^{64}$ In his reply Smuts remarked - avoiding a debate on Transylvania and referring only to Bukovina and Bessarabia - that bringing together the Roumanian people into one state was a question "worthy of consideration" and that "it was in the interest of Austria-Hungary to have a friendly and satisfied Roumania on her flank." 65

Then they came to the most difficult of all questions, Italy. Mensdorff asked how the British could defend the national principle when they promised the Italians territories inhabited predominantly by Slav population in Dalmatia. He also reminded Smuts that Trieste had never belonged to Italy. Smuts frankly acknowledged that he was not familiar at all with the details but insisted on ceding Trentino to the Italian state. Mensdorff's reply was that „after the treachery of Italy" Vienna did not wish to make any concession to her, whereupon Smuts remarked that the reason of why Italy had been induced to desert Austria-Hungary was that the latter held Italian-populated territory. In spite of the manifestly different positions Smuts concluded his report on an optimistic note: in his opinion the Dual Monarchy was prepared for a compromise even if Mensdorff had not expressly acknowledged it. He formed the impression that "the Austrian mind was in an accommodating mood". 66

In retrospection the historian cannot easily understand on what grounds Smuts based his optimism because actually Mensdorff had not given any serious promise to the Allies. We can assume that by the end of 1917 even Karl himself, supposing a German victory, had practically given up the aim of concluding a separate peace with the ,Entente' (let us add: missing perhaps the best opportunity during the war to ensure the survival of his empire). Lloyd George himself came to the logical conclusion after getting acquainted with the position represented and defended by Mensdorff that "at that date the negotiation of a separate peace with Austria was out of the question". It is remarkable, however, that in his comment upon the Smuts report he added also: "at that date we did not contemplate a complete break-up of the Austrian Empire". ${ }^{67}$

Mensdorff suggested in Geneva that the Allies should state their peace terms clearly and unequivocally. Lloyd George thought this idea "fruitful”, and on 5 January 1918 he

63 LLOYD GEORGE, 1485.

64 LLOYD GEORGE, 1484.

65 LLOYD GEORGE, 1484.

66 LLOYD GEORGE, 1485.

67 LLOYD GEORGE, 1489. 
summarized the military and political objectives of Britain in a speech to the trade unions. This important speech is fully included in the "War Memoirs" as an appendix. We find in it the following crucial statements: "Nor are we fighting to destroy Austria-Hungary"; "the break-up of Austria-Hungary is no part of our war aims". ${ }^{68}$ There can be no doubt that Lloyd George did not agree with those who wished the Habsburg Monarchy to disappear from the political map of Europe. But he also emphasized in the same speech that "unless genuine self-government on true democratic principles is granted to those Austro-Hungarian nationalities who have long desired it, it is impossible to hope for the removal of those causes of unrest in that part of Europe which have so long threatened its general peace." 69 His declaration in favor of the preservation of the Habsburg Monarchy, even if he stressed the need for the fundamental transformation of its historically evolved internal structure, elicited at once the sharp criticism of the group around the journal "New Europe". ${ }^{70}$

After this speech Vienna indicated again her willingness to resume talks with London. The British representative in Berne, Sir Horace Rumbold received a message that Count Czernin wished to meet Lloyd George in Switzerland. ${ }^{11}$ The British government took the position that such a meeting would attract too much unwanted public attention. Personally - as he emphasizes in his memoirs - Lloyd George "was strongly in favor of keeping up these communications with Austria", so he urged the Cabinet to take advantage of every overture which might lead to an agreement with Austria-Hungary. Finally Jan Smuts and Philip Kerr were commissioned to travel to Switzerland and ascertain the exact meaning of the new Viennese overture. ${ }^{72}$ They arrived in Berne on 9 March - the significant delay was the result of the latent but effective opposition of the Foreign Office. In the words of Fest, Lloyd George's decision not to slam the door to further talks "amounted to a victory of the Cabinet over the Foreign Office" ${ }^{73}$ However, the loss of time proved to be significant because in the meantime the political orientation of the Dual Monarchy, strongly influenced by the German war propaganda, had been modified once again. As is well-known, in March 1918 the Habsburg Monarchy put all her cards on the success of the large-scale German offensive in the West. Consequently, Alexander Skrzynski had been authorized by the foreign minister practically only to listen to what the British said. In his memorandum prepared after the interview with Baron Skrzynski Kerr pointed out: „Due to the effect of the collapse of Russia before the German advance, coupled with the improved military situation of Germany in the West... Count Czernin may have decided that his best policy was to abandon separate peace negotiations..." Kerr also alludes to the possibility

68 LLOYD GEORGE, 1511; 1514 (The Peace Declaration, APPENDIX II).

69 LLOYD GEORGE, 1514.

70 For this reaction see in more details: Zbynek A. B. ZEMAN, The Break-Up of the Habsburg Empire, 1914-1918, London 1961, 179-183.

71 LLOYD GEORGE, 1498. A "highly-placed Austrian", Baron Skrzynski informed Sir Rumbold that according to Vienna "there were in the addresses recently delivered by Mr. Lloyd George and by President Wilson a number of points about which there was agreement between the Government of His Majesty and that of Austria-Hungary". 72 Kerr accompanied Smuts to Geneva in December 1917. According to the "War Memoirs" both Smuts and Kerr travelled to Berne in March 1918; Fest writes only of Kerr. See: LLOYD GEORGE, 1500-1501; FEST, 202.

73 FEST, 202. 
that Czernin may have decided "to do business via America because the U.S.A. was not tied to Italy by treaty...". ${ }^{74}$

Whatever plans Czernin may have had, on 2 April he committed a huge political mistake which led to his downfall and resignation. He boasted in the Municipal Council of Vienna that the French had asked for peace-talks. The French premier Georges Clemenceau became immensely incensed at hearing this and out of revenge he disclosed the letter of Karl written on 24 March. ${ }^{75}$ This unprecedented act, heavily condemned by Smuts, proved to be a political bomb: it discredited the Dual Monarchy in the eyes of its German ally and put an abrupt and final end to the talks between London and Vienna. In Britain the advocates of the destruction of the Monarchy gained the upper hand and there remained no opportunity for Lloyd George to continue the efforts to detach Austria-Hungary from Germany. Arthur Balfour, the Foreign Secretary is quoted as saying: "The French have now destroyed any chance of allied negotiations with the Austrian Emperor."76 This development - a crushing defeat of the strategy espoused by Lloyd George in connection with AustriaHungary - left in turn little chance for the survival of even a completely transformed large Central-European state.

In the final part of his account Lloyd George emphasizes: "It may be of some interest, not untinged with regret to conjecture what might have been the effect on the settlement of Europe if peace had been concluded with Austria in the spring of 1918. The Austrian Empire would have remained; instead of breaking up into a number of independent states... there would have been perhaps a dozen autonomous dominions all owing allegiance to the Austrian Crown and working harmoniously together for their common interests" ${ }^{77}$ These words reflect clearly the preferences of Lloyd George. In a similar vein one of his close associates, Leopold. S. Amery, commenting upon the radical dismantling of the Habsburg Monarchy remarked in his political autobiography published in 1953: a "more limited settlement" may have resulted in greater stability for Europe... ${ }^{78}$

\section{Abstract}

The present study aims to offer a contribution to the research on the diplomatic history of World War I, focusing its attention on the relation between Great Britain and the AustroHungarian Monarchy in 1917-1918. To be more precise, it attempts to highlight the personal role of the prime minister of Britain, Lloyd George in shaping this relation. The fundamental assumption of the article is that, Lloyd George was committed to detach the Dual Monarchy from Germany by means of a separate peace. The study focuses on the repeated attempts to negotiate a secret arrangement with the Monarchy after Emperor Karl came to the throne in 1916 and initiated a new foreign policy, with the view to secure peace for his empire and eventually to break with Berlin. The author analyses in details the

\section{LLOYD GEORGE, 1502.}

75 See for more details: FEJTŐ, 257-260 (Chapter XXVI). ZEMAN supposes that Czernin - though he took part in the negotiations with Sixtus - did not know about the precise content of the letter. See: ZEMAN, $1971,133$.

76 FEST, 223.

77 LLOYD GEORGE, 1502.

78 Leopold Stanley AMERY, My Political Life, Vol. II, War and Peace, 1914-1918, London 1953, 105. 
secret mission of Prince Sixtus in the first half of 1917 and the confidential talks between Jan Smuts and Albert Mensdorff in December 1917. The primary source for this work is the War Memoirs of Lloyd George, but the memoirs of Prince Sixtus are also extensively utilized. The major conclusion of the author is that Lloyd George realized that in Central Europe a large - federalized - political structure might serve better international stability than a large number of small states divided along national lines and inimical to one another.

\section{Keywords}

Karl's peace initiative, Sixtus letter, Sixtus-mission, separate peace, secret negotiations, Smuts-Mensdorff talks, Italian claims, transformation and preservation of the Monarchy

\section{References}

AMERY, Leopold Stanley: My Political Life, Vol. II, War and Peace, 1914-1918, London 1953.

ARDAY, Lajos: Térkép, csata után. Magyarország a brit külpolitikában, 1918-1919, Budapest 2009.

BROOK-SHEPHERD, Gordon: The Last Habsburg, London 1968.

CALDER, Kenneth J.: Britain and the Origins of the New Europe, Cambridge 1976.

CZERNIN, Ottokar: Im Welktriege, Wien 1919.

FEJTŐ, Ferenc: Rekviem egy hajdanvolt birodalomért - Ausztria-Magyarország szétrombolása, Budapest 1990.

FEST, Wilfried: Peace or Partition. The Habsburg Monarchy and British Policy, 1914-1918, London 1978.

HANAK, Harry: Great-Britain and Austria-Hungary during the First World War. A Study in the Formation of Public Opinion, London 1962.

KANN, Robert A.: Die Sixtusaffäre und die geheimen Friedensverhandlungen ÖsterreichUngarns im Ersten Weltkrieg, Wien 1966.

LLOYD GEORGE, David: War Memoirs, I-II, London 1936-1938.

MANTEYER, Georges de (ed.): Austria's Peace Offer, 1916-1917, London 1921.

PRIBRAM, Alfred: Austria-Hungary and Great Britain, 1908-1914, Oxford 1951.

TAYLOR, Alan J. P.: The Struggle for Mastery in Europe, 1848-1919, Oxford 1954.

ZEMAN, Zbynek A. B.: The Break-Up of the Habsburg Empire, 1914-1918, London 1961.

ZEMAN, Zbyněk A. B.: A Diplomatic History of the First World War, London, 1971. 